\title{
ACCOUNTABILITY OF CORPORATE TOWARDS ENVIRONMENTAL ISSUES THROUGH THE LENS OF CORPORATE SOCIAL RESPONSIBILITY (FINANCIAL) AND BUSINESS RESPONSIBILITY (NON-FINANCIAL) REGULATIONS WITH REFERENCE TO TOP 30 COMPANIES ON NIFTY
}

\author{
Arpit Sharma $^{1 *}$, Sanjeevi Shanthakumar ${ }^{2}$ \\ $1^{*}$ Gujarat National Law University, Research Scholar, India; \\ ${ }^{2}$ Gujarat National Law University, Vice-Chancellor, India; \\ *Corresponding Author Arpit Sharma, e-mail: arpitt.sharmaa@gmail.com; vc@gnlu.ac.in;
}

Received October 2021; Accepted November 2021; Published January 2022;

DOI: https://doi.org/10.31407/ijees12.104

\begin{abstract}
Purpose: The purpose of this article is to comprehend the response of the corporate towards the environmental concern and how the corporate restore the environment by spending CSR funds on environmental activities. The purpose of this article also comprehends the non-financial environmental disclosure by the corporates and its compliance. Design / Methodology/ Approach: In this study, there is a sample of the top 30 companies selected on NSE excluding banks (regulated by RBI) down the line from 2017 to 2020. The methodology is to check the CSR spending on the environment from the total CSR of top 30 companies and for non-financial disclosure on the environment, this paper checked the compliance of BRR by corporates. Practical Implication: The study on the corporate performance toward the environmental concern and provide comprehensive viewpoints for contributing financial and non-financial by implementing the policies through CSR and BRR. Originalities/value: This paper contributes the literature, as well as the resultant of the corporate compliance on regulation 34, read with regulation 101(2) of Securities and Exchange Board of India (Listing Obligations and Disclosure Requirements) Regulations, 2015. Finding: The finding of this paper show the mixed results the corporate spend more amount on CSR does not have a positive relationship with more spending on environmental activities. The other finding regarding nonfinancial disclosure where again the mixed resultant some of the top companies non-complied under Principle 6 of National Voluntary Guidelines in Business Responsibility Report.
\end{abstract}

Keywords: Business responsibility report, corporate social responsibility, corporate environmental responsibility, environmental disclosure, national voluntary guideline. 